\title{
A quiescência da produção intelectual
}

Luiz Carlos de Abreu ${ }^{1}$

A

Revista Arquivos Brasileiros de Ciências da Saúde (ABCS) publica três números anuais desde a sua fundação, dando sequência à Revista Arquivos Médicos do ABC. Tem propiciado um conjunto de artigos interessantes, de aplicabilidade direta no dia a dia das diversas espe-

cialidades da área da saúde, cumprindo, inexoravelmente, o papel de um periódico científico de divulgação local, regional e nacional. No ritmo que está, alçará, muito em breve, a divulgação de seu conteúdo na América Latina, visto que estará inserida na metodologia Scielo de divulgação de conteúdo científico em periódico aberto e gratuito. Os artigos aqui publicados passam, então, a ter maior visibilidade tanto no Brasil como na América Latina, bem como nos demais países de língua portuguesa, inclusive na Europa, África e Ásia.

Assim, o volume 35 (1) traz publicações no campo da Ortopedia e Traumatologia. Não é tarefa fácil prover conteúdo científico ordenado no campo da cirurgia, em virtude das particularidades dessa área do conhecimento, quer pela falta de recursos para manutenção do projeto, quer pela escassez de produção intelectual na forma de artigos. Mesmo assim, nossos colegas cirurgiões têm trazido, desde os tempos de fundação dos periódicos específicos da área, várias e importantes contribuições. Na atualidade, há periódicos solidificados no campo da Ortopedia e Traumatologia, com publicações periódicas e de qualidade reconhecidamente internacionais. Neste contexto, a ABCS traz importante contribuição na divulgação de artigos desse campo do conhecimento, pois propiciará ao seu leitor o acesso irrestrito aos 17 artigos da área de Ortopedia, demonstrando claramente que seu legado é contribuir para a difusão e a disseminação do conhecimento no campo da ciência da saúde.

Um conjunto de artigos originais, relatos de caso e revisões constitui importante material de consulta e apreciação dos colegas médicos das diversas especialidades, em especial aos ortopedistas e clínicos gerais, bem como aos enfermeiros, fisioterapeutas, educadores físicos e outros profissionais, que utilizam desses conhecimentos no seu dia a dia para o exercício profissional. Artigos sobre deformidades ortopédicas, fraturas, tipo de cirurgia, entre outros, propiciarão ao leitor uma vasta, atual e necessária aquisição de conhecimento nesse campo, crucial ao melhor desempenho profissional e intelectual dos membros da equipe multi, inter e transdisciplinar. Artigos sobre escoliose idiopática do adolescente, espondilolistese degenerativa, lesões esportivas, tratamento cirúrgico das fraturas do úmero, do polegar em gatilho congênito, da síndrome do túnel carpal, da técnica de miniincisão, experimentais no campo da consolidação óssea, da resistência dos nós na osteossíntese, dos acromiale sintomático, da analgesia congênita, da instabilidade do cotovelo, sarcoma extraósseo, nas síndromes ortopédicas do tipo Klippel-Trenaunay, fraturas dos arcos costais e apresentação de classificação angular para protrusão acetabular são os assuntos abarcados neste número.

Assim, a ABCS contribui para a divulgação de trabalhos científicos que colaboram para o desenvolvimento das atividades ortopédicas e traumatológicas no campo multiprofissional, tanto na clínica como no ensino e na pesquisa.

As ciências biomédicas estão em permanente desenvolvimento, o que por si só justifica a divulgação desse importe material, gerando a disseminação e o acesso universal aos interessados. A ABCS está cumprindo o seu papel, fruto da dedicação de muitos atores anônimos, os quais parabenizo e estimulo a continuar este trabalho incansável, em prol da imparcialidade e divulgação da Ciência.

Parabéns a todos e boa leitura! 